\title{
Investigation of H19/Rsal Polymorphism in Children With Low Birth Weight in Pernambuco, Brazil
}

\author{
Paula Maia ${ }^{1,2}$; Paulo Souza ${ }^{3}$; Hildson Dornelas Angelo ${ }^{4,5}$; Igor Santos $^{3}$; Danyelly Martins $^{6}$; \\ Jose Lima Filho ${ }^{6}$; Maria Mascena Maia ${ }^{3,{ }^{*}}$ \\ ${ }^{1}$ Federal University of Vale do Sao Francisco, Petrolina, Brazil \\ ${ }^{2}$ Dom Malan Hospital, Petrolina- Pernambuco, Brazil \\ ${ }^{3}$ Department of Biology, Federal Rural University of Pernambuco, Recife-Pernambuco, Brazil \\ 4 Federal Institute of Pernambuco, Campus Garanhuns, Garanhuns- Pernambuco, Brazil \\ 5 Poder-Graduated Program in Genetics, Federal University of Pernambuco Recife- Pernambuco, Recife, Brazil \\ Post-Graduated Program in Genetics, Federal University of Pernambuco Recife- Pernambuco, Recife, Brazil
${ }_{\text {Keizo Asami Immunopathology Laboratory, Federal University of Pernambuco, Recife-Pernambuco, Brazil }}$ \\ ${ }^{*}$ Corresponding author:Maria Mascena Maia, Federal Rural University of Pernambuco, Dom Manuel de Medeiros Avenue, Dois Irmaos, P.O. Box: 52171-900, Recife/Pernambuco, Brazil. \\ Tel:+55-8133206314, E-mail: mascenadiniz@hotmail.com
}

Received: February 14, 2014; Accepted: January 17, 2015

\begin{abstract}
Background: $H 19$ is a strong candidate gene for influencing birth weight variation and is exclusively imprinted maternally. In an attempt to understand the relationship of this gene polymorphism with low birth weight children, we investigated association of H19/RsaI polymorphism with low birth weight and normal birth weight in children and their mothers.

Objectives:The aim of our study was to establish the association between H19 gene polymorphism and LWin children born in Pernambuco, state of Brazil.

Patients and Methods: It were selected 89 children, 40 low birth weight (LW) and 49 normal birth weight (NW) and 71 mothers (40 mothers of newborns NW and 31 mothers of newborns LW) attended at Dom Malan Hospital, Petrolina, Pernambuco - Brazil. Peripheral blood samples were collected from patients and genomic DNA was extracted and detected by electrophoresis agarose gel, stained by Blue Green Loading Dye. DNA PCR amplification was done using the primers $\mathrm{H} 1$ (sense) and $\mathrm{H} 3$ (antisense). PCR products were digested with RsaI and electrophoresed on agarose gel stained by ethidium bromide. Statistical analyses were performed using the program BioEstat version 5.0.

Results: The RsaI polymorphism in the H19 gene showed that genotype frequencies did not differ statistically between low birth weight $(\mathrm{AA}=12.5 \%, \mathrm{AB}=45 \%, \mathrm{BB}=42.5 \%)$ and control $(\mathrm{AA}=8.6 \% \mathrm{AB}=36.73 \%, \mathrm{BB}=55.10 \%$ groups $)$ and the allele frequencies were not significantly different $(\mathrm{P}=0.2897)$. We also did not observe any association between maternal H19 allele polymorphism and low birth weight newborns $(\mathrm{P}=0.7799)$ or normal birth weight children $(\mathrm{P}=0.8976)$.

Conclusions: The small size of sample may be the explanation for these results; future studies with more patients are needed to confirm the effect of H19/RsaI polymorphism on birth weight of LW newborns.
\end{abstract}

Keywords: Birth Weight; Infant Low Birth Weight; Genotype; Alleles; Polymorphism Genetic

\section{Background}

Neonatal ( 0 to 28 days of life) mortality represents about $70 \%$ of infant mortality in Brazil, an indicator of living conditions and health of the population. Birth weight $<2,500 \mathrm{~g}$ is pointed out as the most influential factor in determining neonatal morbidity and mortality. The fetal growth is regulated by genetic, environmental, hormonal, nutritional, and placental factors (1).

IGF2 and H19 genes are of special interest, since in addition to their reciprocal imprinting patterns, they are closely linked on chromosome 11 in humans and are strong candidate genes for influencing birth weight variation (2). The human $\mathrm{H19}$ is an untranslated gene that lies within $200 \mathrm{~kb}$ downstream of the paternally expressed allele (3). The maternally expressed $\mathrm{H} 19$ gene itself does not encode a protein, but the RNA has growth potentially suppressing functions (4) through inhibiting translation of IGF2 RNA (5). IGF2 appears to be an important growth factor and low expression of its gene might be associated with intrauterine fetal life damaging resulting in low birth weight (LW) of newborn and may predispose the individual to chronic diseases in post-natal life such as obesity and hypertension (6). Studies have shown an association between birth weight with polymorphisms of IGF2 and H19 genes (7).

\section{Objectives}

The aim of our study was to establish the association between $\mathrm{H} 19$ gene polymorphism and LW in children born in Pernambuco, state of Brazil.

Copyright (C) 2015, Growth \& Development Research Center. This is an open-access article distributed under the terms of the Creative Commons Attribution-NonCommercial 4.0 International License (http://creativecommons.org/licenses/by-nc/4.0/) which permits copy and redistribute the material just in noncommercial usages, provided the original work is properly cited. 
Maia P et al.

Table 1. Allele and Genotype Frequencies of the Polymorphism in the Gene H19/RsaI in Newborns With LW and NW and Mothers of Newborns With LW and NW a, b

\begin{tabular}{|c|c|c|c|c|}
\hline Frequencies & Children NW & LW & Mothers NW & LW \\
\hline \multicolumn{5}{|l|}{ Genotypes } \\
\hline $\mathrm{AA}$ & $4(8.16)$ & $5(12.5)$ & $2(5)$ & $6(19.35)$ \\
\hline $\mathrm{AB}$ & $18(36.73)$ & $18(45)$ & $17(42.5)$ & $12(38.71)$ \\
\hline $\mathrm{BB}$ & $27(55.10)$ & $17(42.5)$ & $21(52.5)$ & $13(41.94)$ \\
\hline \multicolumn{5}{|l|}{ Alleles } \\
\hline A & $26(26.53)$ & $28(35)$ & $21(26.25)$ & $24(38.71)$ \\
\hline B & $72(73.47)$ & $52(65)$ & $59(73.75)$ & $38(61.29)$ \\
\hline
\end{tabular}

a Abbreviations: HW, Hard-Weinberg equilibrium; LW, Low weight; NW, normal weight.

b Data are presented as No.(\%).

Table 2. P value and OR (95\% CI) Calculation for Different Types of Allels and Genotypes a

\begin{tabular}{|c|c|c|c|c|c|c|c|c|}
\hline & \multicolumn{4}{|c|}{ Genotypes } & \multicolumn{4}{|c|}{ Alleles } \\
\hline & $\begin{array}{l}\text { Children } \\
\text { NW } \times \text { LW }\end{array}$ & $\begin{array}{l}\text { Mothers } \\
\text { NW } \times \text { LW }\end{array}$ & $\begin{array}{l}\text { Children NW } \\
\times \text { Mothers NW } \\
\end{array}$ & $\begin{array}{l}\text { Children LW } \\
\times \text { Mothers LW } \\
\end{array}$ & $\begin{array}{c}\text { Children NW } \\
\quad \times \text { LW } \\
\end{array}$ & $\begin{array}{c}\text { Mothers NW } \\
\quad \times \text { LW } \\
\end{array}$ & $\begin{array}{l}\text { Children NW } \\
\times \text { Mothers NW } \\
\end{array}$ & $\begin{array}{l}\text { Children LW } \\
\times \text { Mothers LW } \\
\end{array}$ \\
\hline P Value & 0.4873 & 0.1689 & 0.7705 & 0.7169 & 0.2897 & 0.1613 & 0.8976 & 0.7799 \\
\hline OR $(95 \% \mathrm{CI})$ & & & & & $0.67(0,35-1.27)$ & $0.56(0,28-1.15)$ & $1.01(0.52-1.98)$ & $0.85(0.43-1.69)$ \\
\hline
\end{tabular}

a Abbreviations: HW, Hard-Weinberg equilibrium; LW, Low weight; NW, normal weight.

\section{Patients and Methods}

\subsection{DNA Extraction}

We selected 89 children, 40 LW and 49 normal birth weight (NW) and 71 mothers (40 mothers of NW newborns and 31 mothers of LW newborns) who attended Hospital Dom Malan, Petrolina, PE-Brazil. Genomic DNA was extracted from peripheral blood. Ethical approval for this study was obtained from the Ethics Committee of the/Faculty of Medicine/UFPE. Written consent was obtained from parents of the subjects.

\subsection{DNA PCR and Genotyping}

DNA PCR amplification was based on Petry and Ong (8) with $H 1$ (sense) and $H 3$ (anti-sense) primers. The PCR products were digested with RsaI 4 hour at $37^{\circ} \mathrm{C}$ and electrophoresed on $1.5 \%$ agarose gel and stained by ethidium bromide.

\subsection{Statistical Analysis}

Statistical analyses were performed using the program BioEstat version 5.0. Genotype and allele frequencies in groups were compared by $\mathrm{I}^{2}$ test with significance set for a P value $<0.05$. Hardy-Weinberg test was used to verify if the genotypes of the control group NW and LW were in equilibrium.

\section{Results}

Allele and genotype frequencies H19/RsaI polymor- phism are shown in Table 1 . We observed in this study that the frequencies of $\mathrm{AA}, \mathrm{AB}$ and $\mathrm{BB}$ genotypes did not differ significantly between $\mathrm{LW}$ and NW children $(\mathrm{P}=0.4873)$ as well as the allele frequencies $(\mathrm{P}=0.2897 ; \mathrm{OR}=0.6)$. Also no association was observed between maternal H19 allele polymorphism and LW newborns $(\mathrm{P}=0.7799$; $\mathrm{OR}=$ 0.85 ) or NW newborns ( $\mathrm{P}=0.8976$; $\mathrm{OR}=1.01)$. Genotype frequencies in both groups did not differ significantly. In the present study, we observed a higher frequency of allele $\mathrm{B}$ for both groups in relation to gene polymorphism H19/RsaI. It was also shown that the value of genotypic frequency of allele B of the gene $H 19$ was higher than the A allele for both NW children (55.10\%) and mothers of NW children (52.5\%).

\section{Discussion}

It was believed that the relationship of IGF2 and H19 could influence birth weight. SNP located in H19 gene that may alter mRNA structure could influence the imprint of IGF2, which is a major fetal growth factor (9). However our results did not reveal an association of H19/ RsaI polymorphism with LW children, outcomes that are consistent with those described by Araujo (10). Study of polymorphism of the IGF2 gene in this same population found no association of this polymorphism with LW children (11).

Despite the few studies on the association of H19 gene polymorphism with LW children, the findings detect association of the polymorphism with the condition of children born with LW. SNPs in the 5' region of the H19 (rs2067051, rs2251375, and rs4929984) gene were asso- 
ciated with birth weight (2). Petry and Ong found that birth weight of offspring showed association with $\mathrm{H} 19$ 2992C > T SNP genotype of mothers (8). The small size of sample may be the explanation for these results; future studies with more patients are needed to confirm the effect of H19/RsaI polymorphism on birth weight of LW newborns.

\section{Acknowledgements}

This study was supported by the Conselho Nacional de Desenvolvimento Cientifico e Tecnologico, Coordenacao de Aperfeicoamento de Pessoal de Nivel Superior. We also thank the staff of the Dom Malan Hospital- IMIP, Petrolina-PE; mothers of children and involved students of medicine-UNIVASF.

\section{Authors' Contributions}

Paula Maia: Concept/design, acquisition of data, drafting of the manuscript. Paulo Souza: drafting of the manuscript, critical revision of the manuscript. Hildson Dornelas Angelo: drafting of the manuscript, critical revision of the manuscript. Igor Santos: critical revision of the manuscript. Danyelly Martins: acquisition of data, data analysis. Jose Lima Filho: critical revision of the manuscript and approval of the article. Maria Mascena Maia: drafting of the manuscript, critical revision and approval of the article.

\section{References}

1. Avaliacao nutricional do recem-nascido. Falcao MC. Pediatria. 2000;22(3):233.

2. Pattern of the insulin-like growth factor II gene expression during early mouse embryogenesis. Lee JE, Pintar J, Efstratiadis A. Development. 1990;110(1):151.

3. H19 acts as a trans regulator of the imprinted gene network controlling growth in mice. Gabory A, Ripoche MA, Le Digarcher A Watrin F, Ziyyat A, Forne T, et al. Development. 2009;136(20):3413.

4. Tumour-suppressor activity of H19 RNA. Hao Y, Crenshaw T, Moulton T, Newcomb E, Tycko B. Nature.1993;365(6448):764.

5. The H19 transcript is associated with polysomes and may regulate IGF2 expression in trans. Li YM, Franklin G, Cui HM, Svensson K, He XB, Adam G, et al. J Biol Chem.1998;273(43):28247.

6. IGF2 gene variants and risk of hypertension in obese children and adolescents. Faienza MF, Santoro N, Lauciello R, Calabro R, Giordani L, Di Salvo G, et al. Pediatr Res. 2010;67(4):340.

7. Characterization of human and mouse $\mathrm{H} 19$ regulatory sequences. Banet G, Bibi O, Matouk I, Ayesh S, Laster M, Kimber KM, et al. Mol Biol Rep. 2000;27(3):157.

8. Common polymorphism in $\mathrm{H} 19$ associated with birthweight and cord blood IGF-II levels in humans. Petry CJ, Ong KK, Barratt BJ, Wingate D, Cordell HJ, Ring SM, et al. BMC Genet. 2005;6:22.

9. Disruption of imprinting caused by deletion of the H19 gene region in mice. Leighton PA, Ingram RS, Eggenschwiler J, Efstratiadis A, Tilghman SM. Nature. 1995;375(6526):34

10. Araujo FM. Ocorrencia Familial e Associacao de Polimorfismos dos Genes H19 e IGF2 com as Síndromes Hipertensivas Gestacionais 118f. Ribeira o Preto : Faculdade de Medicina, Universidade de Sao Paulo; [cited 26 Feb 2013]. Available from: http://www.teses. usp.br/teses/disponiveis/17/17145/tde-08102008-124957/en.php.

11. IGF2/ApaI polymorphism associated with birth weight in children of the region of Petrolina-PE, Brazil. de Mascena Diniz Maia PF, da Silva TM, Angelo HD, e Silva LW, Gondim Martins DB, de Mascena Diniz Maia M, et al. J Matern Fetal Neonatal Med. 2013;26(3):316. 